\title{
Female and foreign: An intersectional exploration of the experiences of skilled migrant women in Qatar
}

DOI:

10.1111/gwao.12353

\section{Document Version}

Accepted author manuscript

Link to publication record in Manchester Research Explorer

\section{Citation for published version (APA):}

Rodriguez, J. K., \& Scurry, T. (2019). Female and foreign: An intersectional exploration of the experiences of skilled migrant women in Qatar. Gender, Work \& Organization, 26(4), 480-500. https://doi.org/10.1111/gwao.12353

\section{Published in:}

Gender, Work \& Organization

\section{Citing this paper}

Please note that where the full-text provided on Manchester Research Explorer is the Author Accepted Manuscript or Proof version this may differ from the final Published version. If citing, it is advised that you check and use the publisher's definitive version.

\section{General rights}

Copyright and moral rights for the publications made accessible in the Research Explorer are retained by the authors and/or other copyright owners and it is a condition of accessing publications that users recognise and abide by the legal requirements associated with these rights.

\section{Takedown policy}

If you believe that this document breaches copyright please refer to the University of Manchester's Takedown Procedures [http://man.ac.uk/04Y6Bo] or contact uml.scholarlycommunications@manchester.ac.uk providing relevant details, so we can investigate your claim.

\section{OPEN ACCESS}




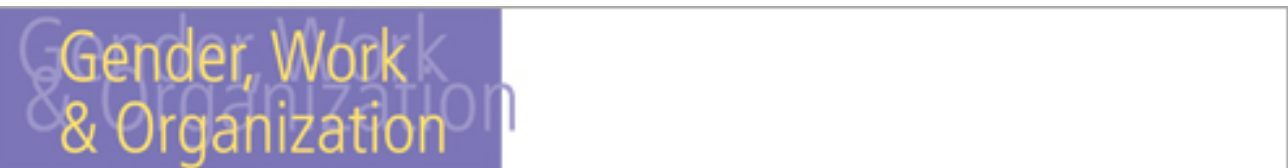

Female and Foreign: An intersectional exploration of the experiences of skilled migrant women in Qatar

\begin{tabular}{|r|l|}
\hline Journal: & Gender, Work \& Organization \\
\hline Manuscript ID & GWO-17-158.R3 \\
\hline Manuscript Type: & Original Article \\
\hline Keywords: & intersectionality, gender, foreignness, skilled migrant women, qatar \\
\hline
\end{tabular}

SCHOLARONE ${ }^{m}$

Manuscripts 


\title{
Female and Foreign: An intersectional exploration of the experiences of skilled migrant women in Qatar
}

\begin{abstract}
This paper explores how the intersection of gender and foreignness shapes the experiences of skilled migrant women. Drawing on interviews with skilled migrant women working in Qatar, we situate their experiences in institutional, organizational and socio-cultural terms to show how the intersection is articulated and mobilized to subordinate, marginalize and exclude them in work and social spaces. Findings show that the intersection is used to reinforce the status of the women as outsiders to the country (foreignness) and its cultural order (gender), resulting in structural and qualitative differences in the experiences of the group. In highlighting their nuanced experiences, we contribute to debates about gender, skilled migration and work in the Middle East. We also contribute to intersectionality debates by expanding the conceptual limits and analytical use of social categories of difference to explain experiences of work and unpack the simultaneity of subject positioning within institutional, organizational and socio-cultural dynamics.
\end{abstract}

Keywords: skilled migrant women, intersectionality, gender, foreignness, Qatar

\section{Introduction}

Despite high levels of participation in global labor markets, skilled migrant women's experiences are shaped by instances of discrimination, disadvantage and lack of opportunity, insecure employment conditions and lack of acceptance of their professional legitimacy (Hutchings et al., 2012; Kuptsch, 2015; Moghadam, 2015). There is an emerging body of work (c.f. Metcalfe, 2008; Willoughby, 2008) exploring these issues in the context of the Middle East, where a patriarchal system of exclusion and segregation impacts women's participation in the labor market. For instance, Gulf Cooperation Council (GCC) countries (i.e. Bahrain, Kuwait, Oman, Qatar, Saudi Arabia, and the United Arab Emirates) are acknowledged to have extreme labor market segmentation, whereby all women are under-represented in employment, and a large majority of foreign women are employed in low level service work and subject to 
strict regulatory frameworks given their non-national status (Baldwin-Edwards, 2011). This poses important challenges for skilled migrant women working in this region, where they are a minority within a minority.

To date, the experience of skilled migrant women in the Middle East has received limited attention (see Glasze, 2006; Harrison \& Michailova, 2012). Analytically, the two dominant approaches exploring skilled migrant women's experiences of work adopt an 'add women, mix and stir perspective' or a 'gender perspective' (Timmerman et al., 2015: 3). The first compares women's experiences to that of men, and the second, despite using gender as a category, treats it in isolation. While the gender perspective has helped to advance discussions because it recognizes the fluid nature of gender dynamics, gender does not operate in isolation and its intersection with other social categories of difference, whilst important, remains largely overlooked in debates about gender and skilled migration. Recent discussions about intersectionality in work and organizations (e.g. Rodriguez et al., 2016) highlight that, in order to better understand what shapes experiences of work, we need to examine how gender intersects with other categories of difference with a view of unveiling the role of intersections in the location of individuals and groups within dynamics, processes and arrangements in particular contexts. In the context of the Middle East, these discussion are starting to be developed more insightfully (see for example, Kemp and Rickett, 2018), yet there is much scope to problematize the ways in which cultural, political and institutional features of the context shape the day-to-day lives of this group (McCall, 2005; Mäkelä et al., 2011; Shortland, 2015).

In this paper, we explore how social categories of difference intersect to shape skilled migrant women's experiences in Qatar. In particular, we focus on gender and foreignness. The importance of looking at the intersection of these categories is rooted in their contextual relevance in the organization of work and social life, in particular the ways in which the categories are deployed institutionally, organizational and socially to define, legitimize and perpetuate subject positioning. For instance, in her auto-ethnographic account of her experience of living and working in Qatar, DeJong (2014) alludes to the centrality of her gender and foreignness noting that, "I felt estranged twice, one for not being a man, secondly for not being able to become one of the Arabs" (p. 115). This reflects what Kemp and Rickett (2018:355) see 
as having 'dual minority' status for women working in these contexts, stemming from both their gender and foreignness. The dynamics at the point of the intersection is the central tension picked up by this paper, which is related to what we see as the features of the intersectional double-burden experienced by skilled migrant women. Whilst it could be argued that skilled migrant women share similarities with local women as a result of gender segregation and gendered social dynamics in Qatar, as well as similarities with expatriate men on the counts of their foreignness; skilled migrant women have a particular status as 'foreign women' which we see as unique to the structural and subjective features of their experiences in this context (see Cole, 2009; Rodriguez, 2018).

Throughout the paper, we use the term 'skilled migrant' to refer to a particular group who are educated and working in professional occupations outside of their country of origin. It has previously been argued that there is a lack of conceptual clarity (over skill level and migration type) when it comes to the notion of skilled migrant (ICMPD, 2005) and that research in management and organization studies has a tendency to switch or combine the term with expatriate (self-initiated or company assigned) (Crowley-Henry et al., 2016). Our definition encompasses a range of perspectives and areas of research, which is reflected in our review of the literature. Moreover, we seek to challenge dominant perspectives of skilled migration, which do not interrogate the impact of intersecting social categories (Zander et al., 2010). In doing so, we enable a deeper and more critical understanding of the experiences of skilled migrant women, locating them within the "historically and socially constituted mosaic of intersecting differences" (Metcalfe and Woodhams, 2012:134).

The paper explores the following questions: How do gender and foreignness as social categories of difference intersect to shape skilled migrant women's experiences in Qatar? In what ways are gender and foreignness used to position skilled migrant women? How do these categories help us to understand the diverse experiences of this group? Drawing on interviews with eight skilled migrant women working in Qatar, we show how the intersection of gender and foreignness is used as part of patriarchal regulatory regimes that locate the women within fixed social categories that sustain narratives of difference. These overlook their status as skilled migrants and reinforce particular subject positioning within organizational and social spaces. The paper 
advances understanding of how intersections are articulated and mobilized within institutional, organizational and socio-cultural structures and dynamics in ways that position and regulate skilled migrant women and shape their experiences. In addition, the paper offers a broader understanding of foreignness as a social category of difference and how it intersects with gender in ways that subordinate and disadvantage skilled migrant women.

The paper is organized as follows. First, we discuss the usefulness of an intersectional lens to explore the experiences of skilled migrant women in the Middle East. We then explain the methodology and provide details of the empirical study. Findings are then presented and analyzed. The analysis is structured in two sections; in the first section we discuss how the intersection is articulated and mobilized institutionally and organizationally to disadvantage skilled migrant women's participation in the labor market and opportunities for development and career progression. In the second section we turn attention to how the intersection operates as a mechanism to control and subordinate women in social and cultural terms. In the final section we conclude, discussing the significance of the findings for discussions of the experiences of skilled migrant women in global labor markets, as well as the theoretical value of the intersection for the exploration of their experiences. We also identify directions for future work.

\section{The value of an intersectional lens to explore the experiences of skilled migrant women in the Middle East}

Following the tradition of intersectionality of discussing subordinate groups at the point of intersection, in this paper we set out to explore how gender and foreignness as categories of difference shape the experiences of skilled migrant women in Qatar. Much has changed around the discourse and use of intersectionality since its introduction in the mid-1980s, with scholars adapting it to address issues that were not the focus of intersectionality when it was initially articulated (Crenshaw, 2014). In particular, intersectionality has gained momentum in management and organization studies, where it is used to understand the dynamics of inequality, oppression, subordination and marginalization that affect particular groups, not just Black women (Rodriguez et al., 2016; Rodriguez, 2018). 
Alongside this expansion in the use of intersectionality, there is an important critique about how its use to study groups other than Black women repackages intersectionality for universal consumption and in doing so, risks re-marginalizing black women and women of color (Jibrin \& Salem, 2015). However, whilst this is a valid concern, in its very conceptualization intersectionality provides a counter argument to essentialism because it offers a lens to capture the fluidity of dynamics arising from temporal and spatial shifts in power relations. In this respect, it is precisely the flexibility of intersectionality as a conceptual, methodological and analytical tool which allows us to fight universalism.

In this respect, the analytical strengths of intersectionality as both a theoretical and analytical framework are especially relevant in the Middle East, given the large number of foreign nationals working in this region. The focus on complexity, multiplicity and simultaneity, intersectionality allows us to interrogate the ways in which social categories of difference are used and deployed to include, exclude, discriminate and marginalize individuals and groups (Brah \& Phoenix, 2004; Yuval-Davis, 2006). This is fundamental given that we all lead intersectional lives and there is not a fixed positioning for either victims or oppressors because systems of oppression are multiple, overlap and operate simultaneously (Hill-Collins, 2004; Rodriguez 2018).

The key foundational category of intersectional analyses is gender, which is explored in relation to its intersection with other social categories of difference, like race, class and age. In this paper, we use foreignness as a relevant social category in a similar manner as it has been used by others (see Acker, 1990, 2008; Fournier, 2002; Newburry et al., 2006; Johansson and Śliwa, 2014) to discuss the constructed and contextual nature of women's experiences of otherness in work and organizational settings. These discussions allude to practices to 'keep women at bay' under the assumption that they do not belong in work settings. In this paper we engage with the idea of foreignness that builds up from these discussions, and expand its conceptualization to include material aspects of difference that seem relevant to a more inclusive articulation of foreignness (e.g. being a foreign national and looking different). 
It is worth noting that we are not looking to engage with foreignness as a universal category that conflates all women who are foreign nationals in a setting; instead, we see foreignness as "a dynamic quality which will produce different effects depending on how and by whom it is mobilized, and for what purpose" (Johansson and Śliwa, 2014:26). The richness of this use sees foreignness as a way of highlighting the binaries of difference in relation to context-dependent materialities, such as normative expectations of behavior, language and appearance, which signify the challenges of living as an Other (Kristeva, 1991:103; Ralph and Staeheli, 2011).

In intersectional terms, foreignness is a complex multidimensional category because its articulation is inherently racialized and also relies on context-specific materialities to shape and reinforce social hierarchies of belonging (Walsh, 2006; Kaufman, 2012). In looking at gender and foreignness, we keep within the tradition of intersectional work of engaging with the complexity of social categories and their meaning, as well as how this complexity differs within a specific group (see Collins, 2001; 2015; McCall, 2005). We see foreignness as a construct of implicit intersections (see Bowleg, 2008); as a category, it is itself articulated by the intersection of several categories of difference, such as racio-ethnicity, age, class, as well as non-class forms of social division (see Anthias, 2001) and in a manner similar to gender, the notion of difference is central to foreignness.

However, in many cases foreignness has not been explicitly used to refer to difference, despite alluding to how "categories of self/other and native/foreign are continually lived and contested through communicative practice" (Mitra, 2014:70). As Mitra (2014) has noted, foreignness relates to perceptions about not-being rather than on the features of being. Despite creating both a site of familiarity/belonging with an in-group and a site of otherness/un-belonging within a dominant group, the alien status of the foreign presents itself as an unresolvable exclusionary puzzle because the foreign is seen as "the one who does not belong to the state in which we are" (Kristeva, 1991:96).

In the case of the Middle East, these categories are of particular relevance as they are seen to sustain dominant patriarchal structures of social location and subject positioning (Moghadam, 2003). Extant work focusing on the Middle East (e.g. Joseph and Slyomovics, 2001) has 
highlighted the historical importance of patriarchal regimes and patriarchal relationality in societal structures and social interactions, which traverse social and work lives. Institutional and cultural barriers embedded in business systems affect women in the region, regulating both their presence and visibility in work settings (Metcalfe, 2008; Metcalfe et al., 2009). Our exploration of this issue departs from the premise that we must not assume that experiences are uniform for all women because the structure of social power relations and resulting dynamics are both fluid and situated (Collins, 1988; Acker, 2006, 2010; Holvino, 2010; Dhamoon, 2011).

In this respect, an intersectional angle is useful to explore how difference in the context of the Middle East is articulated through discourse and "how that affective representation is signified and mediated by the body and experienced as a lived reality" (Mirza, 2013:13). For instance, Hutchings et al. (2012) have noted that expatriate women (self-initiated or company assigned) face complexities linked to prejudice in the Middle East. We see an important step in understanding how this prejudice operates in the interrogation of the role played by governance and institutional regimes in the creation of distinctions based on gender and foreignness. These distinctions could be seen to emerge as a result of 'embodied intersectionality' (Mirza, 2013), whereby the intersection between the material dimensions of difference (e.g. the visibility of gender, the physical dimensions of foreignness) and the cultural dimensions of difference (e.g. gender roles, the relationship between nationality and belonging) shape the subjective position, social location and experiences of the women.

Drawing on the centrality of the nuances of difference in shaping the experiences of foreign women working in Qatar, we adopt an intersectional lens that brings together gender and foreignness and locates them at the core of an analytical framework to explore the social and political positioning of women. This facilitates capturing multiple overlapping levels of disadvantage, which otherwise would slip through unnoticed (Crenshaw, 2016). For example, in the context of GCC countries, all non-national workers, despite their level of skills, are subject to the regulatory regimes established by policies of localization. These policies aim to maintain foreign workers at the margins of social, political and organizational life, establishing distinctions between national and foreign in order to privilege the employment and development of the local workforce (Abdalla, 2006; Williams et al., 2011). This disproportionally affects 
skilled migrant women by adding another layer of complexity to the group's positioning in the context. In that respect, it is relevant here to 'move on from gender' as a single-defining category (Collins, 1999) because other categories overlap in ways that affect skilled migrant women in unique, more fluid, complex and multidimensional ways than what each individual form of inequality would do (Anthias, 2012; Phoenix and Pattynama, 2006; Hulko, 2009; Holvino, 2010). The previous discussion serves as the starting point to our argument that in the case of skilled migrant women in the Middle East, gender and foreignness seem an important point of intersection to explore in order to understand the power dynamics that underpin rigidities and realities of inequalities, mobility restrictions, and lack of progression that have a disproportionate effect on their experiences in this region (Kofman and Raghuram, 2006; Zander et al., 2010).

\section{Methodology}

The aim of this paper is to explore how gender and foreignness intersect to shape the experiences of skilled migrant women in Qatar. We adopted an intersectional lens in order to emphasize "the shifting and contested nature of the different axes of power in specific social situations and the location of individuals and groupings along these axes" (Yuval-Davis, 2011:165). As a methodology and a method (Winker and Degele, 2011), an intersectional lens facilitated the understanding of the experiences of inequality faced by women and the problematizing social processes of categorization that affected them. Intersectionality allows for distinct theoretical projects to mutually benefit from coming together (Davis, 2008); in this case, discussions about gender and foreignness in the context of skilled migration.

\section{Research Context}

Qatar provides an interesting context to explore the experiences of skilled migrant women not only due to the under-representation of and consequent lack of empirical understanding about the Middle East in the literature (Metcalfe, 2008), but also given the tensions between a traditional culture that reinforces segregation on the basis of gender and foreignness amidst a continuing need for migrant labor, including women (Knez et al., 2014). Table 1 provides information about participation in the labor market, where the overwhelming majority is men, with women representing just $13.4 \%$ of all employees in the economically active population. 
Nevertheless, despite the centrality of the rhetoric and policies of localization (Qatarization), which seek to significantly increase the proportion of nationals in the labor force through quotas and preferential treatment (Kamrava, 2009), the labor market participation of Qataris remains low at 5\%. Qatari women make up 36\% of all Qatari employees, reflecting wider trends of increased labor market participation by women across the GCC (Willen et al., 2016). However, despite recognition of positive changes to their participation in employment in the last 25 years, a large majority of these women (68\%) are employed in government departments. There is limited participation of Qatari women in mixed-gender private sector organizations (Felder \& Vuollo, 2008) and top level positions -just 15\% (7,035) of all legislators, senior officials and managers are women, of which $31 \%(2,181)$ are Qatari (QSA, 2017).

This overall under-representation of women in the workforce in the Middle East has been mainly attributed to the patriarchal system that keeps women at the margins of economic activity and restricts them to the confines of the private sphere. However, some research (e.g. Ross, 2008) has argued that these explanations overlook the role of the oil industry as the main economic activity that has created an 'oil-induced patriarchy' where both the employment practices and dynamics within organizations in this sector have shaped what happens in the country's labor market. For instance, Metcalfe (2007) has reported that companies in this sector support gender segregation through subsidies for sex-separate offices and educational facilities, which has limited the career development of women. Looking at the specific treatment of women in the Middle East, Moghadam (2003) notes that the role of stratification by class, ethnicity, education and age also plays a role in the position of women in society. This stratification reinforces cultural norms that locate women in subordinate positions because regardless of their level of education, they are still subject to institutional and socio-cultural structures that govern their personal and family status and position them as second-class citizens.

******INSERT TABLE 1 HERE $* * * * * * * *$

Sampling and data collection 
Data reported in this paper were gathered through semi-structured face-to-face interviews with eight skilled migrant women working in a public shareholding organization in the oil and gas based industry in Qatar. The organization is fully owned by Qatari shareholders and conducts all business from within Qatari borders. 88\% of the workforce in the organization is comprised of foreign nationals. The research was granted ethical approval by the researchers' institution and was conducted in line with the institution's Code of Good Practice in Research. Access to participants was facilitated by the Managing Director of the organization and individuals were contacted via an email invitation to participate in the study. Participants self-selected to take part. As previously noted, skilled migrant women are under-represented in the Qatari workforce, which presented challenges for accessing a larger number of participants.

Interviews were conducted at the organizational premises and followed a protocol that asked participants about their experiences of being a skilled migrant in this context, reasons for moving to Qatar, family and social life in the context, their experiences as women in this context, their experiences at work, in particular interactions with colleagues, line managers and clients, as well as questions about their career development and prospects. The questions allowed us to explore their lived experiences as foreign women working and living in Qatar, and the data collected helped us to understand the ways in which intersectional inequality operations in a different geography and temporality to shape the experiences of this particular group (Rodriguez et al., 2016). Interviews lasted on average one hour and were recorded and transcribed in full. To maintain participant anonymity, for the purposes of our reporting all names have been anonymized. All participants were in professional office roles. Given the potential for participants to be identifiable in the Qatari context due to their hierarchical status within the organization, we do not provide information about their specific roles (see Table 2 for information about participants).

\section{****INSERT TABLE 2 HERE****}

Data analysis

In this paper, we adopt an intra-categorical approach (McCall, 2005) to support our interest in examining the complexity of the intersectional experiences of skilled migrant women, 
simultaneously challenging binary thinking that dichotomizes men, male and masculinity against women, female and femininity (Linstead \& Pullen, 2006). Following the tradition of personal story as a main source of experiential data (Holstein and Gubrium, 2000), we focused on individual accounts. As Ludvig (2006) has noted, "it is through narration that the axes of identity and subjectivity become explicit" (p. 249). Narratives are not inseparable from institutions and events that individuals experience every day, and the act of using narrative to talk about experiences reveals much of the meaningfulness of events for individuals (Bochner, 2001).

As previously stated, our focus on the categories of gender and foreignness is rooted on the relevance of the intersection of these categories to position foreign women in the work and social domains within the Qatari context. In our analysis we highlight the relevance of the institutional, organizational and socio-cultural context to understand how intersections operate as part of systems of differentiation that shape the experiences and positioning of this group (see Choo and Ferree, 2010; Dhamoon, 2011; Brah and Phoenix, 2013).

We structured the data analysis following an iterative process that involved individual and joint coding. We started our analysis of the data by independently reading the interview transcripts and formulating codes that we identified as emerging from participants' accounts (see the first level codes in Figure 1). The codes were identified from the interview responses by participants; for example, we asked questions about the process of entry to the country, their interactions with migration authorities, what it was like to be a woman in the Qatari context, their interactions with line managers and peers and their activities and interactions outside of work.

For the second coding we focused on grouping categories based on our interest in situating the experiences of the women in institutional, organizational and socio-cultural terms. Another element of this second step in our coding process was to address the extensiveness and potential unmanageability of first code categories in qualitative data (see Gioia, 2004); for this, we aimed at further data reduction to facilitate our interpretation within the intersectional framework, jointly looking for similarities and differences in each other's coding. Where codes were similar we sought to agree on terminology. In cases of discrepancies we either reassigned or re-coded 
the data. For our final step, we grouped the codes into theoretical categories to show how gender and foreignness as categories of differentiation were mobilized (see the second level codes in Figure 1).

There is a tension in intersectional work related to balancing the expected analytical depth when exploring intersections, against the risk of infinite regress whereby there may be categories within categories, which risks not defining the boundaries of the analytic effort of the intersection (see Rodriguez et al., 2016). Our decision to code in relation to the categories looked to address this. Our third and final step was to focus on the intersection of the categories of gender and foreignness, where we aggregated the codes based on how we identified them as articulating an integrated framework that shaped the experiences of the women in our sample (see the aggregate dimensions in Figure 1).

In the spirit of the interpretive tradition of qualitative research and mindful of the complexity and diversity in how intersectionality is used and understood, in particular the lack of a distinct intersectional methodology (Bowleg, 2008; Nash, 2008; Shields, 2008, Cho et al., 2013), we crafted our intersectional interpretation focusing on what allowed us to reflect on the points of intersection. In this respect, we drew inspiration from Cole's (2009) questions: (1) who is included in this category? (2) what role does inequality play and (3) where are the similarities? These questions helped us to focus on the interdependency of the categories, the nuances in the positioning of the categories as part of hierarchies of power, privilege, and disadvantage, and the commonalities across the categories found in the experience of being dominant or subordinate (Rodriguez, 2018).

An important consideration in qualitative work is the extent to which the complexity in the process of data analysis is captured in the way the analysis is represented (Procter \& Randall, 2015). In this respect, we recognize that our approach is one way where there are others in which intersectional analyses could be crafted. The intention remains that findings could be made sense of within the theoretical framework that locates the intersection of gender and foreignness within the institutional, organizational and socio-cultural dynamics of the context, 
and that this helps us to show how resulting dynamics shape the material and relational experiences of skilled migrant women in this context.

****INSERT FIGURE 1 HERE****

Findings and analysis: Understanding the experiences of skilled migrant women in Qatar

In the following sections we discuss how gender and foreignness, as social categories of difference, intersect to shape skilled migrant women's experiences in Qatar. The findings are organized in two sections. In the first section we show how the intersection operates in institutional and organizational terms to disadvantage skilled migrant women. In the second section, we show how the intersection operates as a mechanism that regulates and subordinates skilled migrant women in social and cultural terms.

\section{The intersection of gender and foreignness as a location of institutional and organizational disadvantage}

Accounts by participants emphasized how gender and foreignness shaped their participation, interaction, visibility, opportunity and recognition in the workplace and ultimately played a role in their lack of career progression. Their accounts alluded to struggles for legitimacy at work, reflecting their perception that they were outsiders:

"[The sector] anyways tends to be male oriented, and you come to Qatar, and it's almost dominated by men, so I don't think at [organization], they knew what to do with me. I think they expected me to just sit in the office and keep the back seat. When you come from a culture where you're used to going to meetings and discussing freely, it's quite shocking when that's not expected of you [...] I don't feel when I first came, people actually used me as a [occupation], and that was frustrating [...] I know the other companies we deal with, they don't have one female [occupation] and non-Qatari." (Margaret, British) 


\begin{abstract}
"Men tend to look at you as a secondary citizen. They feel they are stronger, and you are not able to do your job as well as them, your abilities are only this much. They also think that all the top positions should be for males and they can progress better. It's very male dominated here. And I think because of the mentality; that becomes a barrier for the woman to advance in her career.” (Naomi, British)
\end{abstract}

Foreign women find themselves in an odd positioning within the organizational space. On the one hand, the presence of skilled migrant women in professional roles challenges the gender social order because Qatari women would not normally occupy such roles and as a result of gender segregation practices that are embedded in employment structures, local male peers as well as local clients would not expect to interact with women (Felder and Vuollo, 2008; Metcalfe, 2008). These accounts highlight differences in treatment experienced by skilled women in relation to men in similar positions and where the intersection of gender and foreignness is used to exclude, marginalized and undermine them. For instance, despite Margaret being highly qualified and experienced, both her exclusion from meetings and her restricted participation in discussions were down to the fact that she was a foreign woman, which was unusual for the sector and occupation. In a similar vein, Naomi notes that men question women's ability to perform top roles. Further expanding on the impact of the maledominated setting, Naomi mentioned that that, as a result of how Qatarization policies mobilize the idea that there are too many foreigners in Qatar, she faced challenges as a foreign woman as a result of perceptions from Qataris that "they are out of jobs because of people like me".

In addition, due to the structure of economic life, Qatari men would be unlikely to compete with Qatari women for jobs in the private sector as the salaries are deemed to be low and the working hours too long (Kapiszewski, 2006). In this respect, the presence of foreign women in the workplace is complicated not only by the relevance of foreignness inherent to the policies of localization, but also the dynamics of gendered workplaces. Ultimately, participants' accounts revealed how the intersection is invoked in ways that negatively impact the professional standing and career opportunities of skilled migrant women.

\title{
Gendered interactions at work
}


On the back of the gendered dynamics that complicate the presence of foreign women, accounts reflect tensions related to the interactions between foreign women and Qatari men in the context of dynamics of social governance that prioritize male identities:

"At work you have to be very formal when dealing with a [Qatari] man here, people can get the wrong idea and you can't get close or affectionate like we do back home" (Tala, Filipina).

Foreign women face the challenges of navigating reconfigured forms of social subordination in the workplace that seek to regulate interactions. This regulation speaks to the complexities of the interrelationship between gender, workplace dynamics and Islamic values in maledominated work settings (Metcalfe, 2006). In this context, skilled migrant women, by virtue of being in a mixed-gender work setting, unsettle the strict gender roles in Qatari society and a way in which their presence is regulated involves informal rules underpinned by understandings of appropriate female behavior.

\section{Organizational opportunities}

In addition to challenging gender norms, skilled migrant women also faced challenges related to the expectations of locals about skilled migrant workers in professional roles. The maledominated nature of the environment translated into expectations that skilled migrants in professional roles would be men. This is simultaneously complicated by Qatarization, which presented further barriers and limited opportunities for career development and progression within the organization for foreign nationals. For example, Amanda (British), who had previously worked as a functional director elsewhere in the Middle East, had come to Qatar with the expectation of being promoted to a vacant manager role in her area of expertise and noted the following:

\footnotetext{
"Interviewer: Did you have any expectations coming here?

Amanda: The [Department X] manager role. That's why I came.

Interviewer: And you didn't get it?
} 
Amanda: That's right. And I don't think I will. It will be Qatarized. I have discussed it with senior management but nothing's happened. These are the things that attract people to places, because you feel it's something you can work forward to."

Whilst the presence of foreign women could be seen to challenge patriarchal disadvantage within this context (i.e. a woman employed in a senior position in a setting where local women would not normally hold such positions), it also highlights how structural relations of subordination and oppression are built upon gender and foreignness in ways that frame the experiences of skilled migrant women (Jureidini, 2005). For instance, the political commitment to pursue Qatarization combines with patriarchal practices that limit the participation of foreign women in management and leadership roles (Lari, 2016). Whilst this may also lead to the exclusion of foreign men from such roles, being a woman is used as another reason for exclusion. So for example, women's accounts highlighted that, contrary to foreign men, their appointment to higher level managerial positions did not include expectations that they would mentor a Qatari successor because of their gender - managerial and leadership positions in this context would not normally be filled by women (Felder \& Vuollo, 2008). In the case of Amanda, whilst qualified to fill this role and with a desire to do so, being a foreign woman is invoked to exclude her from this opportunity. The burden of the intersection was also present in a comment by Imee (Filipina), who spoke of her frustrations in trying to achieve promotion:

"I have a feeling I will stay in the same position, not because I am not qualified, but that's the way it's structured here [...] I am able to achieve a senior level in my department, and I feel I have proven myself, but nothing has happened. There is not a lot of movement in the company, Qataris move up, and other nationalities like the white people and the Arabs, but never a Filipino or Asian."

\section{Institutional regulation and control}

An important element in the articulation of foreignness is the role of racio-ethnicity in structuring social location and how it determined differential and unequal social outcomes for the women (see Anthias, 2001). In this respect, the agency of particular groups (e.g. Western white women) was shaped by perceptions about their desirability as foreign migrants where 
whiteness, in particular, could be seen as creating a powerful cultural void of otherness, which allows some of the women to navigate structural dynamics more swiftly. In some circumstances, white foreignness was deployed to challenge the social order; for instance, some participants spoke of invoking foreignness to legitimize non-conformity with expectations of gender-appropriate behavior within organizational spaces:

"I speak up for myself so I don't really have a problem even if men bother me, which they have. And trust me; the men don't like it when you speak up to them. Sometimes you are seen as too much of an independent opinionated westerner, which doesn't do you any favors." (Amanda, British).

An important element of the enactment of foreignness is that, in some cases, it serves to legitimize performing cultural difference and embracing a process of relational differentiation (Choo and Ferree, 2010). Whilst it is important to contextualize Amanda's comment within the particularities of cultural attributions made to the meaning of 'being Western', it also speaks about power differentials in the way being 'a foreign woman' is deployed by skilled migrant women.

\section{The intersection of gender and foreignness as a location of social and cultural subordination}

The social and cultural positioning of the women can be framed within processes linked to their arrival in Qatar. Most accounts highlighted limited prior knowledge and understanding of gender expectations and cultural norms in Qatar. Some indicated that they had assumed dynamics would resemble those of other countries in the Middle East where they had previously lived and worked. However, their experiences suggested that their status as foreign women was embedded as part of the social and cultural fabric of the context:

\footnotetext{
"I didn't really feel any strong culture in Dubai because it was very free and multicultural. Here you have to be a little more reserved, watch what you are wearing etc. Even when you walk on the street, you think twice before you do it" (Kara, Indian)
} 
Interviewer: "So you feel you had to change your attitude or behavior working [here]?" Oneida (Filipina): "Yes of course. The clothes I wear, the things I say. Sometimes I have to hold back."

The unspoken demands placed on foreign women to conform to expectations of the gender order presents a key tension related to the interplay between gender, foreignness and national culture. Dress and interactions between women and men who are not related are important symbolic markers attached to conceptualization of social appropriateness for women, as well as their regulation and location within the social system in the Middle East (Syed \& Van Buren, 2014).

Skilled migrant women's accounts alluded to expectations about their status as professionals serving as defining factors shaping their work experiences in Qatar. These expectations are not unusual of the way skilled migrants view countries in the Middle East, where prior expectations about international experience are characterized by narratives of unproblematic elite positioning (Rodriguez \& Scurry, 2014). In this respect, the social location resulting from the intersection between gender and foreignness poses an important tension for the women as it pitches the understanding of the self as part of a group that engages in unfettered global mobility against the realities of contextual framing of women based on socio-cultural norms that underpin ideas of difference and otherness.

\section{Gender violence and nationality objectification}

Accounts highlighted diversity in the experiences of white and non-white women, which speak to relevance of the visible embodiment of gender and foreignness in the experiences of the women. Stereotyping based on physical features and appearance is central to social distinctions in Qatar, and is used to create hierarchies of individuals and legitimize ideologies of difference (Nagy, 2006; McDowell, 2008a). The accounts by Filipina participants highlighted that their interactions with Qataris appeared to be informed by the visible embodiment of their foreignness and associated stereotypical views of their racio-ethnic identities: 


\author{
"Sometimes you encounter men who show you respect and some harass you. Some are \\ rude and perverted. Few years ago, I would just be standing on the street, and they \\ would throw their numbers at me". (Oneida, Filipina) \\ "[Qataris] treat the white people and the Arabs different to the Asians" (Imee, Filipina) \\ "I experienced harassment in the malls, on the road from men asking me how much, \\ even when I'm with my husband!" (Tala, Filipina)
}

There is a prevalent popular discourse in the Middle East about the sexual availability of foreign women, in particular those from The Philippines and Malaysia. Institutionally, this fetishization has been linked to the large number of women from these two countries undertaking domestic work in Qatar under the GCC's Kafala sponsorship system (Malit and Naufal, 2014). This has seen recruitment agencies target low skilled labor from Southeast Asia. Many of these groups of women have limited labor rights as a result of an unregulated labor market for domestic workers, which see them forced into the sex trade (Ullah et al., 2015). Socially, the commodification of female bodies is rooted in cultural dynamics of power, which have seen domestic workers reporting experiences of physical and emotional abuse from Qatari employers (Falconer, 2014). In addition, unwritten rules legitimize different forms of gender violence against women justified by the need to enforce gendered social governance to sustain societal values. There is an important tension here about the complexity of these mechanisms of social governance as they are sustained by seemingly arbitrary assumptions yet ones that reveal particular ways in which the intersection of gender and foreignness is used to regulate foreign women.

\title{
Gendered cultural norms
}

However, mechanisms of social governance appeared also to be reconfigured, showing ambiguities linked to the layers and interstices of the interplay between appropriateness and belonging. Kandiyoti (1991) has noted that elements of national identity and cultural difference are used as mechanisms to control women in Muslim countries. In the case of our participants, 
this is used to position them as 'other', regulating them by invoking their outsider status despite their engagement in practices of cultural compliance:

\begin{abstract}
"Actually, when I came, this is the first time in my life I noticed I am embarrassed of being a woman. For example, sometimes I just want to go for a walk, all the men are staring at me so hard, I feel so confused, what is this? I never felt like this before! Even though I cover myself, it still happens." (Carmen, Peruvian)
\end{abstract}

There is layered complexity in the embodied reality of otherness as it is constructed both discursively and embodied in practices of dress and behavior (Mirza, 2013). Carmen mentions going for a walk and being stared at despite being 'covered', which reflects social and cultural differences regarding her understanding of respectable femininity in this context, which is articulated as something that goes beyond the issue of dress. Nagy (2006) has noted that social distinctions are central to how Qataris structure relationships with non-Qataris, using physical characteristics and differences in dress and behavior as markers of otherness. In the case of nonQatari women, it is not only the dress code (not being fully covered) but also behavioral markers such as being chaperoned, which are used to differentiate them from other women in public spaces. These expectations are linked to traditional notions of modesty and privacy in Qatari culture, which are rooted in religion and marital status and underpin differential treatment between Qatari and non-Qatari women (Knez et al., 2014).

\title{
Cultural differentiation
}

Qatari women are expected to conform to traditional understandings of moral behavior that center around restrictions on independence and interactions in social spaces; for example being fully covered at all times and chaperoned when alone or with non-family members (Shah et al., 2018). The institutionalization and politicization of women's roles in public social spaces is enhanced by foreignness, and serves to mark differences between Qatari and non-Qatari women (Knez et al., 2014). For instance, Carmen notes that even though she covers herself in an attempt to conform to expectations of dress, she still receives unwanted attention from Qatari men and feels awkward. In this respect, Carmen's experience brings the intersection of being a woman in a public space which behaves in a manner that is foreign to the cultural norms (e.g. 
being unchaperoned), which influences how she is seen and responded to by locals, particularly men.

In addition to socio-cultural mechanisms, gender and foreignness were deployed politically to regulate women. Regulation through entry, residency and exit permits has been used in GCC countries to monitor migration inflow (Baldwin-Edwards, 2011); however, its importance as a rhetorical device to politicize the presence of foreign nationals is significant. Entry to Qatar is heavily regulated, with particular groups (e.g. White nationals from English speaking countries) being favored over others (Atiyyah, 1996). While speaking of the different nuances in the intersections of gender and foreignness for this group of women, most participants reported feeling that these instances were a constant reminder of their status as outsiders; for instance, those who were non-white and not from English speaking countries noted that they had to rely on husbands for visa sponsorship, whereas this was not always the case for white women from English speaking countries. However, within the accounts it also emerged that all foreign women, regardless of their marital status but particularly those who were unmarried/single, were positioned as less desirable to employers than foreign men. In this respect, we observe another layer in the articulation of foreignness, where its categorical complexity is captured through the encapsulation of other social categories, such as age and marital status.

For instance, Amanda (British), spoke of how her employer had "passed a stupid rule" that prevented the hiring of single women following concerns by senior management that two expatriate women had become intimate. In addition, Margaret, also from the UK, explained that as a single foreign woman under 40 , she "didn't get the visa immediately and the organization had to keep reapplying". In her view, the organization had "taken a big risk" in employing her because, as she was informed by her employer, the country did not want women like her (single foreign women under 40). These accounts reveal how foreign women are positioned as an unwanted, undesirable 'other' and perceived as a challenge to the Qatari social order.

An interesting tension emphasized by the accounts of the women in our sample is related to intra-group differences in the way the intersection of gender and foreignness operates. Even when all the women recounted experiences where the intersection is invoked and used as part of 
processes, practices and dynamics that negatively shape their experiences, where in some cases some elements of foreignness (e.g. racio-ethnicity) were brought to the fore, in others, other categories of difference (e.g. marital status and age) to invoke the otherness of the women in this context in ways that subordinate them.

\section{Conclusion}

This paper set out to explore how the intersection of gender and foreignness shapes the experiences of skilled migrant women in Qatar. By situating their experiences in the wider institutional/organizational and socio-cultural context, we have shown the interdependency and simultaneity of gender and foreignness, and how the intersection is mobilized in ways that negatively impact skilled migrant women. In this respect, the paper has taken an important step in interrogating the idea that skilled migrant women enjoy a privileged status in their international work experiences. Contrary to previous work (see Adler, 1987; Stalker \& Mavin, 2011; Kemp \& Rickett, 2018) that has suggested that foreign women are not subject to the same degree of expectations with regards to cultural compliance and occupy privileged positions relative to local women in terms of access to roles and career opportunities, this paper presents evidence that the intersection of gender and foreignness is articulated and mobilized in ways that control, subordinate, marginalize and exclude skilled migrant women in work and social spaces.

We can conclude from our findings that in contexts highly regulated in social, institutional and organizational terms, the intersection of gender and foreignness is used as a marker of the unfamiliar. Foreign women are perceived as outsiders to both the country (foreignness) and its cultural order (gender). In response, their subjectivities are culturally and institutionally regulated, which sees them experience simultaneous dynamics that while allowing forms of inclusion (e.g. participation in the labor market), are simultaneously sustained by forms of exclusion (e.g. having limited progression opportunities). Part of this differentiation is also the reconfiguration of the intersection whereby it operates and is mobilized in ways that shape the experiences of groups of women (e.g. white and non-white) in structurally and qualitatively different ways so "there is not one category of "woman," but many "women" who are different and unequal to men and to each other" (Crenshaw, 1991: 1245; Holvino, 2012:162). 
By highlighting both the inseparability of the intersection of gender and foreignness and the diverse ways in which it operates, we see this intersection as an open empirical question that shapes and is shaped by contextual dynamics and factors. In this respect, the paper also takes the important step of highlighting the relevance of context in the way intersections play out and shape experiences. Highly-regulated environments present an ideal ground for the intersectional exploration that accounts for in-group differentiation because they use difference as a divisive mechanism where the strength of the mechanism relies on the strength of its ability to reinforce notions of difference. The intersection of gender and foreignness helped us to explore and explain this.

Finally, the adoption of broader analytical frameworks like the one we used in this paper, allows for the exploration of the multidimensionality of women of/in systems, arrangements and institutions within specific contexts, in particular the power laden discourses that sustain their experiences (Holvino, 2010). While women's efforts see them as challenging cultural, social and political barriers in the global work arena; their experiences are situated within tensions between global discourses of freedom of movement and local dynamics of discrimination and inequality (Purdie-Vaughns and Eibach, 2008). Exploring the intersection of gender and foreignness in this paper enabled us to get insights into these tensions.

\section{Contributions and directions for future research}

This paper makes three distinct contributions. First, the paper takes intersectionality outside of both the Western context and Western scholarship, unpacking the simultaneity of subject positioning as part of socio-cultural, organizational and institutional dynamics and showing how intersections produce and are produced by systems of differentiation that are context-specific (Choo and Ferree, 2010). In doing so, the paper responds to the call to explore intersectionality across space and time, in ways that consider not only intersections but position them within their interplay with other debates, such as migration (Rodriguez et al., 2016). The paper also shows the importance of analytically embedding the intersection of gender and other categories of difference to understand what shapes the uneven experiences of diverse groups of individuals. 
This adds to debates that call for more nuanced understanding of intersectionality in work and organizations (Rodriguez et al., 2016) and responds to calls for more intersectional analyses of the work experiences of skilled migrants (Ali et al., 2017; Kemp and Rickett, 2018).

Second, the paper contributes to expanding emerging scholarship in the area of gender and international work in the Middle East. In particular, the paper challenges previous research (c.f., Harrison and Michailova, 2012) that has suggested that women engaged in international work in the Middle East do not problematize cultural norms as a barrier to their work adjustment. Findings reported in this paper show how women in Qatar are subjected to personal and professional judgement based on prevailing cultural norms, and how this impacts on their experiences of work. Drawing from the heterogeneity of experiences of skilled migrant women shown in this paper, there is need for more in depth consideration of how sector, profession or organizational type can lead to different experiences in segregated labor markets. In this respect, the paper sets the grounds for more nuanced interrogation of difference and marginalization and their implications for skilled migrant women's experiences (Metcalfe \& Woodhams, 2012).

Third, the paper contributes to the methodological understanding of the analytical use and potential of intersectionality to explain experiences of work. We frame this contribution within calls to engage with the tensions inherent to the structuring of intersectionality as a field of enquiry (McCall, 2005). The intra-categorical approach that informed the discussions in this paper allowed us to reveal the complexity of the lived experiences of skilled migrant women. However, capturing the multiplicity and complexity of these experiences also required us to engage methodologically with intersectionality: on the one hand, we had to delimit foreignness as a social category of difference and delineate its conceptual boundaries, and on the other hand, we had to craft the intersectional analysis mindful of the complexity of the intersection. Where previous works have used nationality and citizenship as markers of foreignness; our study broadens the conceptual boundaries of this category to make it inclusive other categories (e.g. racio-ethnicity, age, class and other non-class forms of social division), which are contextspecific in its articulation. In doing so, we contribute a nuanced exploration that reveals diversity and heterogeneity that goes beyond the categories and instead focuses on their contextual articulation and mobilization. 
Moving forward, we identify much potential in expanding the intersectional exploration of the heterogeneity of skilled migrant women in global labor markets, particularly in the Middle East. We found the intersection of gender and foreignness useful to problematize the fluidity of inequality and disadvantage. In addition, it helped us to understand how these and other social categories of difference (e.g. age, family status, racio-ethnicity and nationality) are mutually constituted and reproduced to frame constructions and interpretations that disadvantage skilled migrant women. However, while we would agree that a productive exposition of difference and its intersectionalities can only be accomplished by problematizing dichotomies such as actual and potential, native and foreign, familiar and strange; further questions remain. In the context of the increasing participation of women in global labor markets, intersectional analytical frameworks are useful to complicate how resulting dynamics interact with notions of a capitalist/imperial/patriarchal/racial colonial world-system. This is an interesting direction that could advance discussions such as the one we have presented in this paper; more specifically, further exploration is needed on how skilled migrant women mobilize, (re)create, expand and defend their positioning to navigate intersectional disadvantage that affects their work, employment and careers, and in the process of doing so, articulate and legitimize alternative positions beyond these dichotomies.

\section{References}

Abdalla, I. A. (2006) Human resource management in Qatar. In Budhwar, P. A. and Mellahi, K. (Eds) Managing Human Resources in the Middle East, Abingdon: Routledge, pp. 121144.

Acker, J. (1990) Hierarchies, jobs, bodies: A theory of gendered organizations. Gender \& Society, 4,2, 139-158.

Acker, J. (2006) Inequality regimes: gender, class and race in organizations. Gender \& Society, 20,4, 441-464.

Acker, J. (2008) Helpful men and feminist support: more than double strangeness. Gender, Work \& Organization, 15,3, 288-293.

Acker, J. (2010) Gendered organizations and intersectionality: Problems and possibilities. Equality, diversity and inclusion: An International Journal, 31,3, 214-224. 
Adler, N. J. (1987) Pacific basin managers: A gaijin, not a woman. Human Resource Management, 26, 2, 169-191.

Ali, F., Malik, A., Pereira, V. \& Al Ariss, A. (2017) A relational understanding of work-life balance of Muslim migrant women in the west: future research agenda, The International Journal of Human Resource Management, 28,8, 1163-1181.

Anthias, F. (2001) The concept of 'social division' and theorizing social stratification: Looking at ethnicity and class. Sociology, 35,4, 835-854.

Anthias, F. (2012) Transnational mobilities, migration research and intersectionality. Nordic Journal of Migration Research, 2,2, 102-110.

Atiyyah, H. S. (1996) Expatriate acculturation in Arab Gulf countries. Journal of Management Development, 15,5, 37-47.

Bair, J. (2014) On difference and capital: gender and the globalization of production. Signs, 40,1, 203-226.

Baldwin-Edwards, M. (2011) Labor immigration and labor markets in the GCC countries: national patterns and trends. Research Paper No. 11, Kuwait Program on Development, Governance and Globalization in the Gulf States, London School of Economics. Available at: http://eprints.1se.ac.uk/55239/1/Baldwin-Edwards 2011.pdf (Accessed 10/11/16).

Bochner, A. P. (2001) Narrative's virtues. Qualitative Inquiry, 7,2, 131-157.

Bowleg, L. (2008) When Black+ lesbian+ woman $\neq$ Black lesbian woman: The methodological challenges of qualitative and quantitative intersectionality research. Sex Roles, 59,5-6, 312-325.

Brah, A. and Phoenix, A. (2013) Ain't I a woman? Revisiting intersectionality. Journal of International Women's Studies, 5,3, 75-86.

Burdsey, D. (2013) The foreignness is still quite visible in this town': Multiculture, marginality and prejudice at the English seaside. Patterns of Prejudice, 47,2, 95-116.

Cho, S., Crenshaw, K. W. and McCall, L. (2013) Toward a Field of Intersectionality Studies: Theory, Applications, and Praxis. Signs, 38,4, 785-810.

Choo, H. Y. and Ferree, M. M. (2010) Practicing intersectionality in sociological research: A critical analysis of inclusions, interactions, and institutions in the study of inequalities. Sociological Theory, 28,2, 129-149. 
Cole, B. A. (2009) Gender, narratives and intersectionality: Can personal experience approaches to research contribute to "undoing gender"? International Review of Education, 55, 561578.

Collins, P. H. (1988) It's all in the family: Intersections of gender, race, and nation. Hypatia, 13, $62-82$.

Collins, P. H. (1999) Moving beyond gender: Intersectionality and scientific knowledge. In Ferree, M. M. (Ed) Revisioning gender, Thousand Oaks, CA: Sage, pp. 261-284.

Collins, P. H. (2001) Black feminist thought: Knowledge, consciousness and the politics of empowerment, London: Routledge.

Collins, P. H. (2015) Intersectionality's definitional dilemmas. Annual Review of Sociology, 41, $1-20$.

Crenshaw, K. (1991) Mapping the margins: Intersectionality, identity politics, and violence against women of color. Stanford Law Review, 43,6, 1241-1299.

Crenshaw, K. (2014) Justice rising: Moving intersectionally in the age of post-everything. LSE Public Lecture, 26 March. Available at: http://www.lse.ac.uk/websitearchive/newsAndMedia/videoAndAudio/channels/publicLecturesAndEvents/player.aspx?i $\underline{\mathrm{d}=2360}$

Crenshaw, K. (2016) The Urgency of Intersectionality, TedWomen, October 2016. Available at: https://www.ted.com/talks/kimberle_crenshaw the urgency_of_intersectionality. Accessed 23/03/17.

Crowley-Henry, M., O'Connor, E., \& Al Ariss, A. (2016). Portrayal of skilled migrants' careers in business and management studies: A review of the literature and future research agenda. European Management Review. DOI: 10.1002/emre.12072

Davis, K. (2008) Intersectionality as buzzword: A sociology of science perspective on what makes a feminist theory successful. Feminist Theory, 9,1, 67-85.

DeJong, J.B.M. (2014) Always Becoming: (De-) (Re-)territorializing: A Social Studies Autoethnography as 'Minor Literature', PhD Thesis, Utrecht University. Available at: https://dspace.library.uu.nl/handle/1874/301072, Accessed 15/06/18.

Dhamoon, R. K. (2011) Considerations on mainstreaming intersectionality. Political Research Quarterly, 64,1, 230-243. 
Falconer, R. (2014) Qatar's foreign domestic workers subjected to slave-like conditions, The Guardian, 26 February. Available at: https://www.theguardian.com/globaldevelopment/2014/feb/26/qatar-foreign-workers-slave-conditions. Accessed 12/07/18.

Felder, D. and Vuollo, M. (2008) Qatari Women in the Workforce, RAND-Qatar Policy Institute Working Paper WR-612-QATAR, August 2008. Available at: https://www.rand.org/content/dam/rand/pubs/working_papers/2008/RAND_WR612.pdf. Accessed 24/04/2017.

Glasze, G. (2006). Segregation and seclusion: the case of compounds for western expatriates in Saudi Arabia. GeoJournal. 66,1-2, 83-88.

Harrison, E. C. and Michailova, S. (2012) Working in the Middle East: Western female expatriates' experiences in the United Arab Emirates. International Journal of Human Resource Management, 23,4, 625-644.

Hill-Collins, P. (2004) Black sexual politics: African Americans, gender and the new racism. New York, NY: Routledge.

Holstein, J. A. and Gubrium, J. F. (2000) The self we live by: Narrative identity in a postmodern world, Oxford: Oxford University Press.

Holvino, E. (2010) Intersections: The simultaneity of race, gender and class in organization studies. Gender, Work \& Organization, 17,3, 248-277.

Holvino, E. (2012) The "simultaneity" of identities. In Wijeyesinghe, C. L. and Jackson, B. W. (Eds) Perspectives on Racial Identity Development: Integrating Emerging Frameworks, $2^{\text {nd }}$ edition, London: New York University Press, pp. 161-191.

Hulko, W. (2009) The Time- and Context-Contingent Nature of Intersectionality and Interlocking Oppressions. Affilia, 24,1, 44-55.

Hutchings, K., Lirio, P. and Metcalfe, B. D. (2012) Gender, globalization and development: a reevaluation of the nature of women's global work. The International Journal of Human Resource Management, 23,9, 1763-1787.

ICMPD (International Centre for Migration Policy Development) (2005) Highly Skilled Migration, Report from the Fourth Coordination Meeting on International Migration. Population Division Department of Economic and Social Affairs United Nations Secretariat New York, 26-27 October 2005. Available at: 
http://www.un.org/esa/population/meetings/fourthcoord2005/P01 ICMPD.pdf . Accessed 10/07/18.

Jibrin, R. and Salem, S. (2015) Revisiting Intersectionality: Reflections on Theory and Praxis. Transcripts: An Interdisciplinary Journal in the Humanities and Sciences, 5, 7-24.

Johansson, M. and Śliwa, M. (2014) Gender, foreignness and academia: an intersectional analysis of the experiences of foreign women academics in UK business schools. Gender, Work \& Organization, 21,1, 18-36.

Joseph, S. and Slyomovics, S. (2001) Introduction. In Joseph, S. and Slyomovics, S. (Eds) Women and Power in the Middle East, Philadelphia: University of Pennsylvania Press, pp. $1-22$.

Jureidini, R. (2005) Migrant workers and xenophobia in the Middle East. In Bangura, Y. and Stavenhagen, R. (Eds.) Racism and Public Policy, Palgrave Macmillan UK. 48-71.

Kandiyoti, D. (1991) Identity and its Discontents: Women and the Nation. Millennium, 20,3, 429-443.

Kamrava, M. (2009) Royal factionalism and political liberalization in Qatar. Middle East Journal, 63,3, 401-420.

Kapiszewski, A. (2006) Arab versus Asian migrant workers in the GCC countries. United Nations Expert Group Meeting on International Migration and Development in the Arab Region, Beirut, 15-17 May. Available at: http://www.un.org/en/development/desa/population/events/pdf/expert/11/P02_Kapiszewsk i.pdf Accessed 04//08/18.

Kemp, L. J., and Rickett, B. (2018) The lived experiences of foreign women: Influences on their international working lives. Gender, Work \& Organization, 25(4), 343-360.

Knez, K. Benn, T. and Alkhaldi, S. (2014) World cup football as a catalyst for change: Exploring the lives of women in Qatar's first national football team - A Case Study. The International Journal of the History of Sport, 31,14, 1755-1773.

Kaufman, E. (2012) Finding foreigners: Race and the politics of memory in British prisons. Population, Space and Place, 18,6, 701-714.

Kofman, E. and Raghuram, P. (2006) Gender and global labor migrations: Incorporating skilled workers. Antipode, 38,2, 282-303.

Kristeva, J. (1991) Strangers to ourselves, New York: Columbia University Press. 
Kuptsch, C. (2015) Inequalities and the impact of labor market institutions on migrant workers. In Berg, J. (Ed) Labor Markets, Institutions and Inequality: Building Just Societies in the $21^{\text {st }}$ Century, Cheltenham: Edward Elgar.

Lari, N. A. (2016) Gender and equality in the workplace _ a study of Qatari women in leadership positions, Durham theses, Durham University. Available at Durham E-Theses Online: http://etheses.dur.ac.uk/11855/. Accessed 28/03/17.

Linstead, S. \& Pullen, A. (2006) Gender as multiplicity: Desire, displacement, difference and dispersion. Human Relations, 59,9, 1287-1310.

Ludvig, A. (2006) Differences between women? Intersecting voices in a female narrative. European Journal of Women's Studies, 13,3, 245-258.

Nagy, S. (2006) Making room for migrants, making sense of difference: Spatial and ideological expressions of social diversity in urban Qatar. Urban Studies, 43,1, 119-137.

Mäkelä, L., Suutari, V. and Mayerhofer, H. (2011) Lives of female expatriates: work-life balance concerns. Gender in Management: An International Journal, 26,4, 256-274.

Malit, F. T. and Naufal, G. (2014). Asymmetric information under the Kafala sponsorship system: Impacts on foreign domestic workers' Income and employment status in the GCC countries, Cornell University, ILR School. Available at: http://digitalcommons.ilr.cornell.edu/workingpapers/177/. Accessed 12/12/15.

Marchand, M. and Runyan, A. S. (2011) Introduction: feminist sightings of global restructuring: old and new conceptualizations. In Marchand, M. and Runyanm A. S. (Eds) Gender and Global Restructuring: Sightings, Sites and Resistances, London: Routledge, pp. 1-24.

McCall, L (2005) The complexity of intersectionality. Signs, 30,3, 1771-1800.

Metcalfe, B. D. (2006) Exploring cultural dimensions of gender and management in the Middle East. Thunderbird International Business Review, 48,1), 93-107.

Metcalfe, B. D. (2008) Women, management and globalization in the Middle East. Journal of Business Ethics, 83,1, 85-100.

Metcalfe, B., Hutchings. K. and Cooper, B. (2009) Re-examining Women's International Management Opportunities and Experiences: A Middle Eastern Perspective. In Ibeh, K. and Davies, S. (Eds) Contemporary Challenges to International Business, London: Palgrave-Macmillan, pp. 232-250. 
Metcalfe, B. D. and Woodhams, C. (2012) Introduction: New Directions in Gender, Diversity and Organization Theorizing-Re-imagining Feminist Post-colonialism, Transnationalism and Geographies of Power. International Journal of Management Reviews, 14,2, 123-140.

Mirza, H. S. (2013) ‘A second skin’: Embodied intersectionality, transnationalism and narratives of identity and belonging among Muslim women in Britain. Women's Studies International Forum, 36, 5-15.

Mitra, R. (2014) Organizing foreignness: Of aliens, permanence and shape-shifters. In Howard, S. C. (Ed) Critical Articulations of Race, Gender, and Sexual Orientation, London: Lexington Books, pp. 65-84.

Moghadam, V.M. (2000) Transnational Feminist Networks: Collective Action in an Era of Globalization. International Sociology, 15,1, 57-85.

Moghadam, V.M. (2003) Modernizing women: Gender and social change in the Middle East. Lynne Rienner Publishers.

Moghadam, V. (2015) Gender and globalization: Female labor and women's mobilization. Journal of World-Systems Research, 5, 2, 366-389.

Nash, J. C. (2008) Re-thinking intersectionality. Feminist Review, 89,1, 1-15.

Newburry, W., Gardberg, N. A. and Belkin, L. Y. (2006) Organizational attractiveness is in the eye of the beholder: The interaction of demographic characteristics with foreignness. Journal of International Business Studies, 37,5, 666-686.

Phoenix, A. and Pattynama, P. (2006) Editorial: Intersectionality. European Journal of Women's Studies, 13,3, 187-192.

Procter, S. J. and Randall, J. A. (2015) Understanding employee attitudes to change in longitudinal perspective. Qualitative Research in Organizations and Management: An International Journal. 10,1, 38-60.

Purdie-Vaughns, V. and Eibach, R. P. (2008) Intersectional invisibility: The distinctive advantages and disadvantages of multiple subordinate-group identities. Sex Roles, 59,5-6, 377-391.

Qatar Statistics Authority (2017). Annual Bulletin Labor Force Statistics 2017. Available at https://www.mdps.gov.qa/en/statistics/Statistical\%20Releases/Social/LaborForce/2017/2_ Labor_Force_2017.pdf. Accessed 01/062018. 
Ralph, D. and Staeheli, L. A. (2011) Home and Migration: Mobilities, Belongings and Identities. Geography Compass, 5, 7, 517-530.

Rodriguez, J.K. (2018) Intersectionality and qualitative research. In Cassell, C, Cunliffe, A and Grandy, G. (Eds) The SAGE Handbook of Qualitative Business and Management Research Methods, London: Sage, pp. 429-462.

Rodriguez, J. K., Holvino, E., Fletcher, J. K. \& Nkomo, S. M. (2016) The Theory and Praxis of Intersectionality in Work and Organizations: Where Do We Go From Here? Gender, Work \& Organization, 23(3): 201-222.

Rodriguez, J. K. and Scurry, T. (2014) Career capital development of self-initiated expatriates in Qatar: cosmopolitan globetrotters, experts and outsiders. The International Journal of Human Resource Management, 25,7, 1046-1067.

Ross, M.L. 2008. Oil, Islam, and Women. American Political Science Review, 102 (1), 107-123. Shah, N. M., Al-Kazi, L. and Husain, A. (2018) Gender Issues, Changing Roles, and Migration: A Review of the Gulf Countries. In Chowdhury, M. and Rajan, S. I. (Eds) South Asian Migration to the Gulf: Causes and consequences, Cham: Palgrave Macmillan, pp. 123142.

Shields, S. A. (2008) Gender: An intersectionality perspective. Sex Roles, 59,5, 301-311.

Shortland, S. (2015) The Purpose of Expatriation: Why Women Undertake International Assignments. Human Resource Management, 55,4, 655-678.

Stalker, B., and Mavin, S. (2011) Learning and development experiences of self-initiated expatriate women in the United Arab Emirates. Human Resource Development International, 14,3, 273-290.

Syed, J. and Van Buren, H. J. (2014) Global business norms and Islamic views of women's employment. Business Ethics Quarterly, 24,2, 251-276.

Timmerman, C., Martiniello, M., Rea, A. and Wets, J. (2015) Introduction. In Timmerman, C., Martiniello, M., Rea, A. and Wets, J. (Eds) New Dynamics in Female Migration and Integration, Abingdon: Routledge, pp. 1-10.

Ullah, A.A., Hossain, M.A. and Islam, K.M. (2015) Migration and Worker Fatalities Abroad, Basingstoke: Palgrave Macmillan.

Willen, B., Perniceni, A., Lohmeyer, R. and Neiva I. (2016) Power Women in Arabia: Shaping the Path for Regional Gender Equality, Global Business Policy Council (GBPC) Research 
Report, A.T. Kearney Ltd. Available at https://www.atkearney.com/diversity-andinclusion/article/-/asset publisher/O7EGSazwBWC9/content/power-women-in-arabiashaping-the-path-for-regional-gender-equality/236833. Accessed July 2018.

Williams, J., Bhanugopan, R. and Fish, A. (2011) Localization of human resources in the State of Qatar: Emerging issues and research agenda. Education, Business and Society: Contemporary Middle Eastern Issues, 4,3, 193-206.

Willoughby, J. (2008) Segmented Feminization and the Decline of Neopatriarchy in GCC Countries of the Persian Gulf. Comparative Studies of South Asia, Africa and the Middle East, 28(1): 184-199.

Winker, G. and Degele, N. (2011) Intersectionality as multi-level analysis: Dealing with social inequality. European Journal of Women's Studies, 18,1, 51-66.

Yuval-Davis, N. (2006) Intersectionality and Feminist Politics. European Journal of Women's Studies. 13,3, 193-209.

Yuval-Davis, N. (2011) Beyond the recognition and re-distribution dichotomy: Intersectionality and stratification. In Lutz, H., Herrera Vivar, M. T. and Supik, L. (Eds) Framing intersectionality: Debates on a multi-faceted concept in gender studies, Farnham: Ashgate, pp. 155-170.

Zander, U., Zander, L., Gaffney, S. and Olsson, J. (2010) Intersectionality as a new perspective in international business research. Scandinavian Journal of Management, 26(4): 457-466. 
Table 1: Number of economically active population (15 years and above) with employee status

\begin{tabular}{|c|c|c|}
\hline \multirow{2}{*}{ All employees } & Qatari & Non-Qatari \\
\hline & 103,944 & $1,950,558$ \\
\hline Total & \multicolumn{2}{|c|}{$2,046,085$} \\
\hline \multirow{2}{*}{ Women } & Qatari & Non-Qatari \\
\hline & 36,287 & 238,687 \\
\hline Total & \multicolumn{2}{|c|}{274,974} \\
\hline \multirow{2}{*}{ Men } & Qatari & Non-Qatari \\
\hline & 64,086 & $1,707,025$ \\
\hline Total & \multicolumn{2}{|c|}{$1,778,457$} \\
\hline
\end{tabular}

Source: Qatar Statistics Authority (2017) 
Table 2: Participants

\begin{tabular}{|l|l|l|l|l|}
\hline Codename & Age range & Nationality & $\begin{array}{l}\text { Number of years } \\
\text { of international } \\
\text { work experience }\end{array}$ & Time in Qatar \\
\hline Amanda & $40-45$ & British & 2 years & 1 year 6 months \\
\hline Carmen & $35-40$ & Peruvian & n/a & 3 years \\
\hline Imee & $45-50$ & Filipina & 2 years & 3 years \\
\hline Kara & $30-35$ & Indian & 11 years & 7 years 6 months \\
\hline Margaret & $40-45$ & British & 7 years & 2 years \\
\hline Naomi & $55-60$ & British & 32 years & 32 years \\
\hline Oneida & $35-40$ & Filipina & 3 years & 7 years \\
\hline Tala & $30-35$ & Filipina & 4 years & 4 years 1 month \\
\hline
\end{tabular}


Figure 1: Data analysis structure

- Experienced harassment from local men on the street

- Men throwing their numbers on the street

- Ashamed to be a woman

Women need to be mindful of verba and physical interactions with male colleagues to avoid offending them

- Women's views are not valued

- Women are excluded from meetings

- Women expected to adapt their behaviour and dress to accommodate local norms

- Limited social interaction between

foreign nationals and Qataris
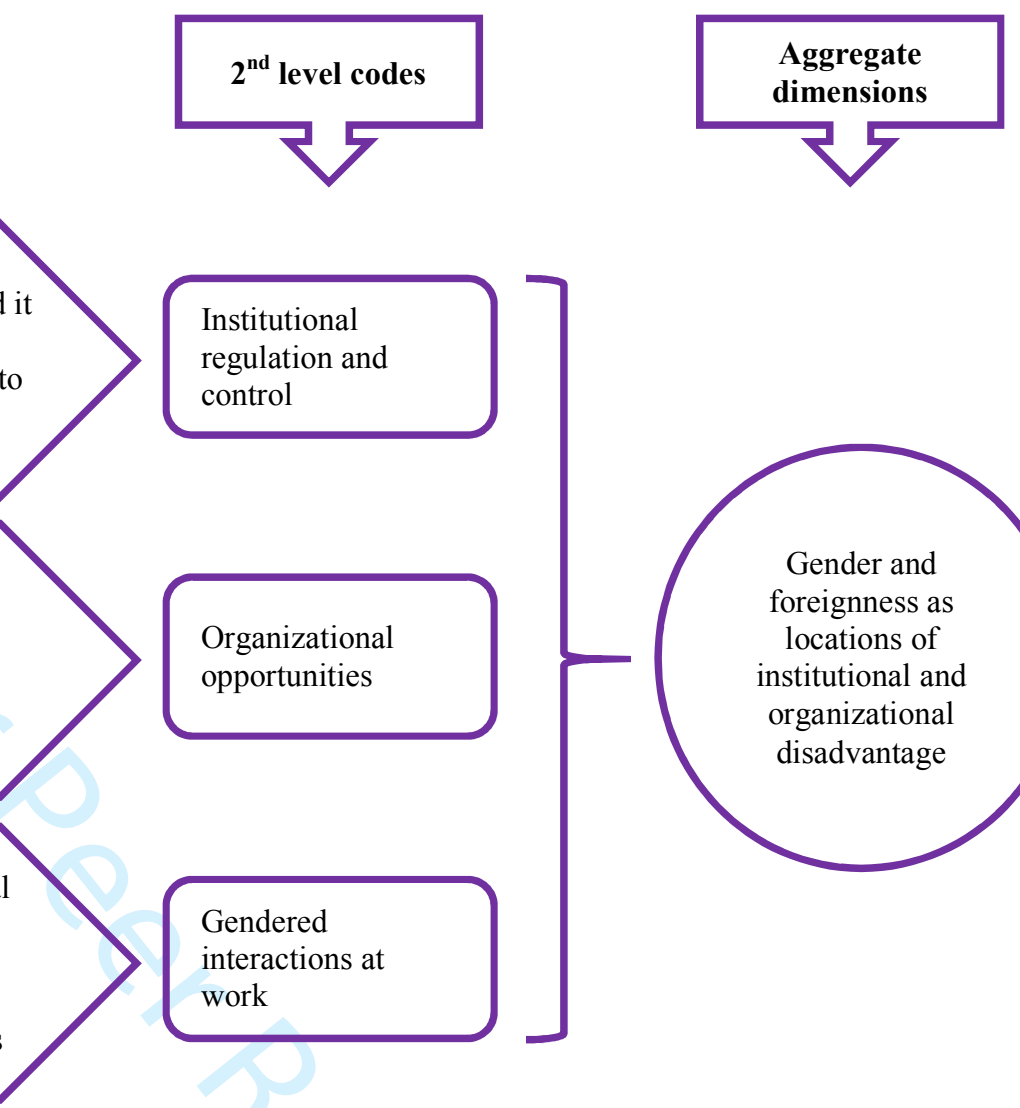

- No management opportunities for

- Treated differently according to nationality

- Limited space for foreign women in Qatari social structures

- Exclusion of non-Qataris from social activities

- Different treatment for Western and non-Western women

Gendered interactions at work

\section{Institutional} regulation and control

Organizational opportunities
Gender and foreignness as locations of institutional and organizational disadvantage
Gender and foreignness as locations for social and cultural subordination
Gendered cultural norms

Cultural differentiation

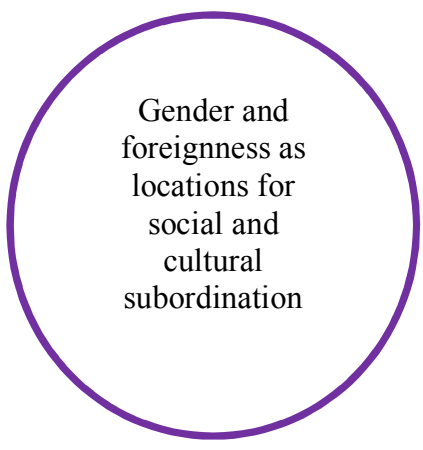

